Gadjah Mada International Journal of Business

May 2002, Vol. 4, No. 2, pp. 129-147

\title{
THE RELATIONSHIPS AMONG DIFFERENT PERFORMANCE MEASURES IN INDONESIAN RETAIL CONTEXT
}

\begin{abstract}
Agus W. Soehadi
Despite research into the links between market orientation and firm performance, research into the detail different measures of performance has been limited. This study develops different measures of performance in retail business and examines their relationship with market orientation. The results suggest that market orientation positively relate to nonfinancial indicators. Also, indirect nonfinancial indicator can be treated as dominant mediator for the relationship between market orientation and financial indicator. Further, the findings suggest that different types of performance measurement affect the magnitude of market orientation and performance association.
\end{abstract}

Keywords: Indonesia; market orientation; retailing; retail performance 
Traditional models of firm performance measurement tend to focus on the achievement of a limited number of key financial measures (for example Gross Margin and Rate of Return). Gross margin is the difference between the net sales revenue and the net direct acquisition cost of the merchandise sold, based on the cost of purchase, adjusted for changes in inventory holdings. It reflects the difference between average buying and average selling prices including any price discounting (O'Riordan 1993: 33). Rates of return is measured as an interest return on owners' investment, calculated at the best net interest rate they could earn elsewhere (Bradley and Taylor 1992).

Matheson et al. (1995) noted that gross margin and rate of return might suffer from differences in accounting practice. Thus, there is a greater risk to lay on financial ratios, if the firms that are trying to compare have different accountancy practice (Varadarajan and Ramanujam 1990). In addition, access to financial data, especially privately held firms, is severely restricted (Dess and Robinson 1984).

In response to the dissatisfaction with financial performance, a number of performance measurement models have been developed. Bourgeois (1980) used indi- rect measures (they called as subjective measures) of financial indicators to measure firm performance, which is asking the perception of top management team about financial performance compared to the immediate competitors. Venkatraman and Ramanujam (1986) added nonfinancial indicators, called as operational indicators, in their models.

Many past studies in marketing have measured firm performance to examine the various impact of marketing strategy content and process issues (e.g., Capon et al. 1990; Narver and Slater 1990; Jaworski and Kohli 1993; Liu and Davies 1997). Yet in marketing strategy and retail marketing literature, there is a little agreement on how firm performance should be measured (e.g. Ailawadi et al. 1995; Burt and Sparks 1997; Chakravarthy 1986; Davies and Kay 1990) (see Table 1). Should retail firm performance be assessed with single or multiple measures, financial or nonfinancial measures, objective or subjective measures, indirect or direct measures, or input or output measures? This article aims to illuminate these questions by focusing on the relationships between different measures of performance in a retailing context.

\section{Table 1. Performance Measurement in Market Orientation Studies}

\begin{tabular}{cllll}
\hline \multicolumn{1}{c}{ Author } & & Objective/Direct & & Subjective/Indirect \\
\cline { 1 - 1 } Droge and Germain (2000) & $\begin{array}{l}\text { Levels of Inventory } \\
\text { (stock-age) }\end{array}$ & & $\begin{array}{l}\text { ROI, ROS and Average } \\
\text { Profit }\end{array}$
\end{tabular}

McGee and Peterson (2000)

Hurley et al. (1998)

\author{
Relative Growth in Customer Customer Satisfaction \\ Count Relative Growth in Service Quality
}

Gross Profit; Net Income Af ter Taxes; Total Sales Growth over the past three years; Overall Performance 
Soehadi-The Relationships among Different Performance Measures in Indonesian Retail Context

Continued from Table 1

\begin{tabular}{|c|c|}
\hline Author & Objective/Direct \\
\hline Judd and Vaught (1988) & $\begin{array}{l}\text { Gross Profit; Net Profit; Gr } \\
\text { Profit Return on Inventory; } \\
\text { Net Profit Return on } \\
\text { Inventory and Stock-turn } \\
\text { Rate. }\end{array}$ \\
\hline McGurr and DeVaney (1998) & $\begin{array}{l}\text { ROA; Change in Working } \\
\text { Capital; Gross Margin; } \\
\% \text { Change in Long-term } \\
\text { Liabilities; Current Ratio; } \\
\text { Long-term Liabilities perce } \\
\text { Sales per employee. }\end{array}$ \\
\hline Pearce (1998) & $\begin{array}{l}\text { Available Market; Store } \\
\text { Traffic Share; Purchase } \\
\text { Yield Rate; Average Gross } \\
\text { Margin Percentage; } \\
\text { Fixed Costs and Average } \\
\text { Investments. }\end{array}$ \\
\hline
\end{tabular}

Burt and Sparks (1997)

Hopkins and Hopkins (1997)

Liu and Davies (1997)

\section{AuthorObjective/Direct}

Martin (1996)

Ailawadi et al.(1995)

Magi and Julander (1996)

O’Riordan (1993)

EVA; MVA; GM/Sales;

Gross Margin
Growth (changes in market share, market share growth, sales growth); Profitability (business unit profitability, ROI, ROS); Customer Satisfaction (customer satisfaction, delivering value to customers); Adaptability (number of successful new products, introduction of new products, time to market for new products) relative to the major competitors.
Operating Margin; Pre-Tax Margin; ROCE; Supplier Credit; Days Stock; Personnel Costs.

Profit and ROE.

\section{Subjective/Indirect} ROS; ROI; Inventory/Sales; Advtg and Promotion/Sales.

Labour Productivity; Space Productivity; Net Profit.
Sales Volume and Profitability.

Market share; profit growth; and ROA relative to market average.

Customer Satisfaction; Customer Loyalty; Perceive Quality. 
GadjahMadaInternationalJournal ofBusiness, May2002, Vol.4,No. 2

\section{Continued from Table 1}

\begin{tabular}{|c|c|c|}
\hline Author & Objective/Direct & Subjective/Indirect \\
\hline Bradley and Taylor (1992) & $\begin{array}{l}\text { Total long-term debt to } \\
\text { shareholder's fund; fixed } \\
\text { assets to current liabilities; } \\
\text { pre-tax profit to net assets; } \\
\text { partnership bonus to pre- } \\
\text { tax profits. }\end{array}$ & \\
\hline Davies and Kay (1990) & $\begin{array}{l}\text { Turnover; Operating Profit } \\
\text { and Market Value: ROA, ROE } \\
\text { and Return to Shareholders; } \\
\text { Real Sales Growth; Operating } \\
\text { Profit Growth; Earnings } \\
\text { Growth and PE Ration; } \\
\text { Stock Level (days) and Sales } \\
\text { per Employee; Added } \\
\text { Value as \% of inputs. }\end{array}$ & \\
\hline Weitzel et al. (1989) & $\begin{array}{l}\text { Sales-per-payroll-hour; } \\
\text { Sales-per-square feet of space. }\end{array}$ & \\
\hline
\end{tabular}

\section{Assessing the Firm Performance}

Two basic issues exist in assessing firm performance are: (1) selection of a conceptual framework with which to define firm performance and (2) identification of accurate available measures that operationalize firm performance (Dess and Robinson 1984). In this article, the authors focus on a conceptual framework, which includes both financial and nonfinancial performance indicators.

Venkatraman and Ramanujam (1986) classified performance measurement based on characteristics of data. Accordingly, there are four types of data, which are direct/objective measures (e.g. data collected directly from firm records or publicly available records or from customer), indirect/subjective measures (e.g. data collected based on the perception of top management about both the current/past performance relative to the target or aver- age industry), financial indicators, and operational indicators (Figure 1).

Financial indicators reflect the fulfillment of the economic goals of the firm and in marketing literature have included profit (Pelham 2000), sales growth (Slater and Narver 1994), and turnover (Diamantopoulos and Hart 1993). Those indicators are also employed in retail research. Davies and Kay (1990) employed sales turnover and sales growth. Ingene (1984) and O'Riordan (1993) note the importance of gross margin in measuring retail performance and Lewis and Thomas (1990) suggested using ROS and ROCE. Nonfinancial indicators focus on those key operational success factors that might lead to financial performance. Nonfinancial indicators in retailing include market share, productivity (labor productivity and space productivity) (e.g. Ingene 1982; 1984; Cronin and Skinner 1984) and stock-turn (Davies and Kay 1990). 
Soehadi-The Relationships among Different Performance Measures in Indonesian Retail Context

Figure 1. A Scheme for Classifying Alternate Approaches for Measuring Firm Performance

\begin{tabular}{|c|c|c|c|}
\hline & $\begin{array}{l}\text { Financial } \\
\text { Indicators }\end{array}$ & $\begin{array}{l}\text { Operational } \\
\text { Indicators }\end{array}$ & $\begin{array}{c}\text { Both } \\
\text { Indicators }\end{array}$ \\
\hline $\begin{array}{c}\text { Direct/ } \\
\text { Objective }\end{array}$ & $\begin{array}{l}\text { Dawes (2000) } \\
\text { Hart and Tzokas (1999) } \\
\text { Sargeant and } \\
\text { Mohammad (1999) } \\
\text { Han et al. (1998) } \\
\text { Bartz and Baetz (1998) } \\
\text { Li and Simerly (1998) }\end{array}$ & Lukas and Ferrel (2000) & \\
\hline $\begin{array}{l}\text { Indirect/ } \\
\text { Subjective }\end{array}$ & $\begin{array}{l}\text { Bhunian (1997) } \\
\text { Matsuni and Mentzer } \\
(2000) \\
\text { Luo and Peng (1999) } \\
\text { Han et al. (1998) } \\
\text { Siguauw et al. (1998) }\end{array}$ & $\begin{array}{l}\text { Braddy and Conin (2001) } \\
\text { Baker and Sinkula (1999) } \\
\text { Bart and Baetz (1998) }\end{array}$ & $\begin{array}{l}\text { Pelham (2000) } \\
\text { Chang et al. (1999) } \\
\text { Vorhies et al. (1999) } \\
\text { Abranson and Ai (1998) } \\
\text { Greenly and Foxall (1998) } \\
\text { Tan et al. (1998) }\end{array}$ \\
\hline
\end{tabular}

Using the conceptualization of firm performance (financial versus non financial indicators) and types of data (direct/ objective and indirect/subjective) as two basic but different concerns in the overall process of measuring firm performance, a six-celled classificatory scheme (shown in Figure 1) is developed.

As Figure 1 indicates, six approaches are conceptualized within a particular cell. For example, in Cell 1, the conceptualizing scheme for firm performance uses financial performance data obtained from indicator/subjective measures (e.g. Capon 1990; Diamantopoulos and Hart 1993), while Cell 4 focuses on eliciting financial data from the perception of top management (e.g. Dess and Robinson 1984; Narver and Slater 1990; Jaworski and Kohli 1993).
Cells 2 and 5 on nonfinancial indicators collected from direct/objective measures (e.g. Buzzell and Wirsema 1981; Conant et al. 1993) and subjective measures (e.g. Golden 1992; Edgett and Snow 1996), respectively. It is readily apparent that these four approaches have a narrow perspective on firm performance (Venkatraman and Ramanujam 1986). Alternatively, combining financial indicators and nonfinancial indicators (Cell 3 and 6) can broaden it (e.g. Brignall et al. 1991; Fitzgerald et al. 1991; Brignall and Ballantine 1996). A classificatory scheme as presented in Figure 1 is useful. It serves as a basis to compare and contrast different measurement approaches. This scheme will be used for classification of performance measurement in retail sector. 


\section{Hypothesis Development}

Throughout the numerous findings in market orientation research, one of the most interesting finding from previous studies is that the type of performance measurement affects the result. For example, if the studies use indirect measurement of performance (managers' or informants' judgements), most the results show a positive link between indirect and direct measurement. On the other hand, if the studies use direct measurement of performance, the results are quite ambiguous (see Table 2). Clearly, the type of performance measurement may affect the results of the study and this is consistent with the notion that each type of performance pro- vides a unique characteristic (Kaplan and Norton 1992). Therefore,

$H_{1}$ : The correlation values of indirectperformance will be significantly higher than direct performance in the marketorientation-performance association.

As can be seen from Table 2, most of the study used indirect measurement. This indirect measure of performance was chosen over direct measurement for several reasons. Firstly, firms are often very reluctant to provide 'hard' financial data (cf. Covin 1991, p.448). Secondly, direct financial measurement on the sample firms might not be publicly available (Dess and Robinson 1984). Apart from this, the validity of this performance measurement

\section{Table 2. The Market Orientation-Performance Association}

\begin{tabular}{|c|c|c|}
\hline & \multicolumn{2}{|c|}{ Performance Measurement/Association } \\
\hline & Indirect & Direct \\
\hline Hooley et al.(1990) & $+/ \mathrm{S}$ & \\
\hline Narver\&Slater (1990) & $+/ \mathrm{S}$ & \\
\hline Doyle\&Hooley 1992 & $+/ \mathrm{S}$ & \\
\hline Ruekert (1992) & & $+/ \mathrm{S}$ \\
\hline Deshpande et al. (1993) & $+/ \mathrm{S}$ & \\
\hline Diamantopoulos and Hart (1993) & & $+/ \mathrm{PS}$ \\
\hline Jaworski and Kohli (1993) & $+/ \mathrm{S}$ & $+/ \mathrm{NS}$ \\
\hline Slater\&Narver (1994) & $+/ \mathrm{S}$ & \\
\hline Greenley (1995a:1995b) & $+/ \mathrm{PS}$ & $+/ \mathrm{NS}$ \\
\hline Orvis (1996) & $+/ \mathrm{S}$ & \\
\hline Pitt et al. (1996) & $+/ \mathrm{S}$ & \\
\hline Avlonitis and Gounaris (1997) & $+/ \mathrm{S}$ & \\
\hline Langerak et al. (1997) & $+/ \mathrm{S}$ & \\
\hline Pelham (1997) & $+/ \mathrm{S}$ & \\
\hline Liu and Davies (1997) & $+/ \mathrm{S}$ & \\
\hline Langerak and Commandeur (1998) & $+/ \mathrm{S}$ & \\
\hline Verhees (1998) & $+/ \mathrm{S}$ & \\
\hline
\end{tabular}

(S) Significant

(PS) Partly Significant

(NS) Non Significant 


\section{Soehadi-The Relationships among Different Performance Measures in Indonesian Retail Context}

was supported by the findings of Dess and Robinson (1984), whose findings is widely confirmed in other studies (e.g. Covin and Slevin 1988). Despite evidence of positive correlation between direct and indirect measures, the relationship between indirect and direct measures in the retailing context remains a gap in our knowledge. Therefore,

$H_{2}$ : There will be significant positive correlation between indirect and direct measures of performance

A further gap is the measurement of marketing inputs measures. Marketing inputs lead to intermediate outputs (nonfinancial indicators) that in turn lead to financial outcomes. Figure 2 presents the conceptual model that maps a path from market orientation to financial indicators. Briefly, the model comprises of three sets of factors: a market orientation, nonfinancial indicators (mediator variable) and financial indicators. The arrows depict general influence flows rather than "causal" effect coefficient to be calibrated empirically. Nonfinancial indicators will mediate the relationship between market orientation and financial indicators.
The market orientation concept is widely believed as a method to evaluate the quality of marketing inputs (Clark 1999). A market orientation is the ability of firms to learn about customers, competitors and environmental forces, to continuously sense and act on events and trends in present and prospective markets (Day 1994). It therefore underpins the ability to outperform competitors and to create long-term superior value for customers. Therefore, a market orientation is one of the key factors determining a firm's financial performance. Thus,

$H_{3}$ : There will be a significant positive correlation between market orientation and nonfinancial indicators.

$H_{4}$ : There will be a significant positive correlation between market orientation and financial indicators.

Apart from this, marketing and retailing scholars are interested in nonfinancial indicators issues. The underlying reason was nonfinancial indicators are assumed to have a positive impact on profitability (Magi and Julander 1996). For example, Ingene (1982) found both labor and space productivity had a significant impact on

\section{Figure 2. The Model of Theoretical Relationships}

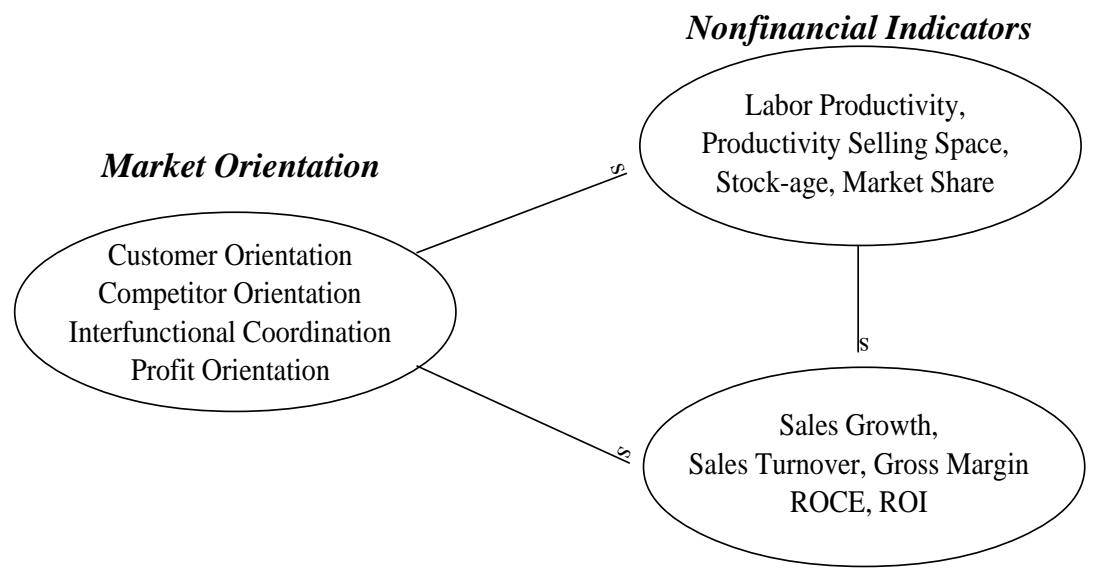

Financial Indicators 
profitability. Other indicators such as market share and stock-turnover is widely believed to be vital for profit performance (Broeren 1981; Buzzell and Wiersma 1981; Duncan et al. 1983). Therefore,

$H_{5}$ : There will be a significant positive correlation between nonfinancial indicators and financial indicators.

\section{Methods}

Preliminary interviews were conducted to ascertain that the items met the needs of the research. Three items were dropped in this process, which are ROCE, ROS and labor productivity. One of the reasons was that not all retail firms were familiar with both financial ratios. Also, based on preliminary observation, only a few retail firms were concerned about labor productivity.

To test the model presented in Figure 2 ; data were collected to assess the relationship between market orientation and retail performance. Names of retailers were culled from different sources; Indonesian Directory, Retail Association, CIC, BPS and Yellow Pages. In total, the number retail firms in the Jabotabek area is 127 000 firms. From Figure 2, only 1820 retail firms could be classified as within the target population based on their size. However, the final number on the sampling list was 1030 retail firms due to the store being closed, having moved, using a wrong address and not being a retail firm.

Each retailer was contacted by telephone to obtain cooperation. Further, we asked them to provide the name of the person who was most knowledgeable about the business strategy that had been conducted by the firm. Almost 60 percent of retail firms did not want to participate in this research. They directly rejected us for several reasons such as firm policy, no interest, too busy and even the "owner is still in Singapore."

Pre-coded questionnaires were mailed to all informants along with a covering letter on university stationary explaining the purpose of the study, and the confidentiality of responses. Surveys were returned to the researcher by pre-addressed, postage-paid envelopes enclosed with the questionnaires. Three or four field follow-ups by telephoning were conducted. Their purpose was to explain the benefit of joining this project, to make sure that respondent understood the questionnaire, and to remind them to return the questionnaire. These procedures resulted in responses from a total of 172 retail firms, a response rate 36.5 percent. After initial screening however only the 159 fully completed questionnaires were used for analysis.

All measures were tested for validity and reliability following the guidelines offered by Jaworski and Kohli (1993) and Byrne (1989). The results of the measurement model of market orientation $\chi_{(74)}^{2}$ were $121.62(\mathrm{p}=.000)$, nonfinancial indicators $\chi_{(4)}^{2}$ was $6.413(\mathrm{p}=.170)$ and financial indicators $\chi_{(2)+}^{2}$ was $2.451(\mathrm{p}=.794)$. Appendix 1 and 2 contains measured characteristics and sample measurement items. Here, the origin of the measures used and the process of purification and assessment convergent validity are briefly discussed.

Twenty-two items of market orientation, six items of nonfinancial indicators and 4 items of financial indicators have been used as input for purification processes. It is important to identify poor items (items which correlate negatively or do not correlate strongly with other items) and eliminate them from the instrument (Churchill 1979). The purifying of instruments relies on the confirmatory factor analysis (Kohli and Jaworski 1993). This process drops seven items of market orien- 
Soehadi-The Relationships among Different Performance Measures in Indonesian Retail Context

tation constructs. To assess the convergent validity, this study follows the Bagozzi and Yi (1991) procedures for inspection of factor variance. Accordingly, convergent validity can be achieved if all factor loadings for specified factors are statistically significant. All items load positively on their specified constructs and the $t$ values associated with each of the loadings exceeds 2.0 (AMOS 3.61 1996). The results confirm the convergent validity of the three constructs

\section{Analysis and Results}

Table 3 shows that the correlation values of indirect measures were higher than the correlation values of direct measures, thus supporting the hypothesis 1 . This finding has confirmed that the type of

Table 3. The Differences Between Indirect and Direct Measures in the Market Orientation-Performance Association

\begin{tabular}{|c|c|c|c|}
\hline Construct & $\begin{array}{c}\text { Indirect } \\
\text { Performance }\end{array}$ & $\begin{array}{c}\text { Direct } \\
\text { Performance }\end{array}$ & $\begin{array}{c}\text { Critical } \\
\text { Ratio (C.R.) }\end{array}$ \\
\hline Market Orientation & $.710^{*}$ & $.309 *$ & $2.05^{*}$ \\
\hline Customer Orientation & $.319 *$ & .220 & -.028 \\
\hline Competitor Orientation & .073 & .137 & .614 \\
\hline Inter-functional Coordination & $.381 *$ & -.029 & $-2.85^{*}$ \\
\hline Profit Orientation & .106 & .213 & -1.33 \\
\hline
\end{tabular}

*) Pair of parameter estimates is significantly different $($ C.R. $>+2.0, p<.05)$

Figure 3. Indirect and Direct Measures

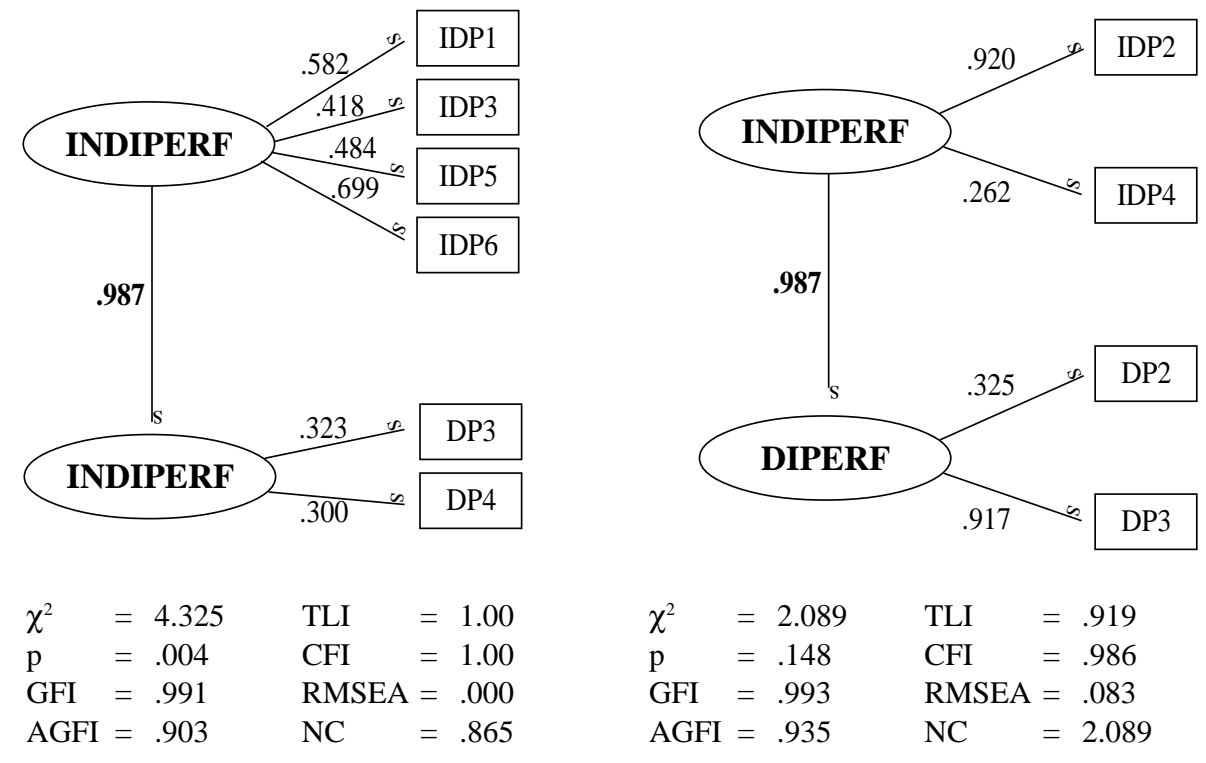

Nonfinancial Indicators

Financial Indicators 
Figure 4. Performance Model

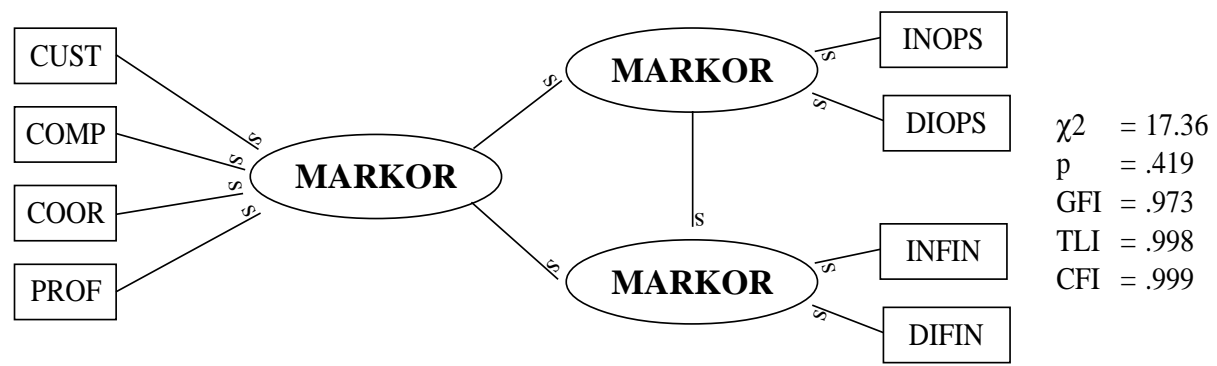

performance measurement influences the magnitude of the effect of market orientation on firm performance. This indicates that the type of performance measurement may affect the results of the study. This is consistent with the notion that each type of performance provides a unique characteristic (Kaplan and Norton 1992).

As predicted by Hypothesis 2, indirect measures have positive correlation with direct measures for both nonfinancial performance and financial performance $\left(\mathrm{b}_{\mathrm{fp}}=.666, \mathrm{p}<.05: \mathrm{b}_{\mathrm{nfp}}=.987, \mathrm{p}<.05\right)$ (Figure $3)$. The result of this study confirms the previous studies (e.g. Covin et al. 1990; Dess and Robinson 1984). This finding supports the underlying assumption in much empirical marketing research that there is a positive relationship between indirect measures and direct measures.

The result of a SEM analysis reveals that market orientation has a significant effect on nonfinancial indicators $\left(\mathrm{b}_{\mathrm{m}-\mathrm{o}}=.515\right.$; $\mathrm{p}<.05$ ) (Figure 4). This finding lends substantial support to the previous findings (e.g. Jaworski and Kohi 1993; Slater and Narver, 1994; Pelham 2000), confirming that market orientation has a significantly positive effect on performance. However, contrary to hypothesis, the relationship between market orientation and financial indicators is insignificant.

This study has confirmed the hypothesis 5 that there is a positive relationship between nonfinancial and financial performance (Figure 4). This implies that nonfinancial indicators can be categorised as mediating variable for market orientation and financial indicators. Therefore, this study supports the Srivastava's et al. (1988) notion that the nonfinancial indicators can be thought as firm assets that are leveraged to produce superior financial performance. In other word, the total effect of market orientation toward firm performance is bigger in the situation of having high level of nonfinancial indicators.

\section{Discussion and Conclusions}

This study has confirmed that there are positive interrelationships among performance measures. It is shown that market orientation affects positively on nonfinancial indicators. This finding is consistent with the expectation and supports the notion that market orientation is an important determinant of firm performance. Market orientation will increase the capability of retail firm to offer high value merchandise or to increase store patronage and sales. Further, it is helping retail firm to make and implement strategic decision better, such as: product assortment, retail price, promotion activities, and customer service. 


\section{Soehadi-The Relationships among Different Performance Measures in Indonesian Retail Context}

However, these findings are not particularly surprising and the contribution of this research lies rather in the consideration of the indirect effects which market orientation has on financial indicators through their impact on the nonfinancial indicators. Previous research has simultaneously considered market orientation impacts on financial performance without considering other variables could possibly mediate the relationship (Han et al. 1998).

In addition to this, the findings suggest that nonfinancial indicators have a positive correlation with financial indicators. The presumption behind many of these nonfinancial indicators is that they are leading indicators of long-run shareholder value (Srivastava et al. 1998). As such, it appears that retail managers should strive to improve nonfinancial performance in their efforts to attain higher financial performance.

Interesting to note, the findings suggest that type of performance measurement approach would affect the magnitude of market orientation and performance association. The indirect measures tend to have a high correlation value relative to the direct measures. In other words, the interpretation or perception of performance will affect the results of the study. If a senior manager feels that his or her company has a deep knowledge about market, and importantly serve consumer better than competitors, regardless of the actual performance, he or she will perceive that company has better performance than competitors. This finding brings to the marketing or strategic research implications that using a single approach to measure firm performance could mislead the results of the research.

The research findings offer important managerial implications. The present study clearly supports a positive effect of market orientation on nonfinancial indicators: market share, productivity selling space, and stock-age. The positive effect of market orientation will give marketoriented retailers a much better chance of improving their profitability. Hence, the ability of retail business to cultivate an appropriate behaviour required to develop better customers' value relative to its competitors is vital for achieving and maintaining superior performance. Further, this finding give retail managers a much stronger basis than intuition and anecdotes for recommending the wisdom of adopting and implementing a market orientation.

Consequently, retail firms are encouraged to continue their efforts in becoming an ever more market-oriented enterprise. As various retail firms learned to be market-oriented, numerous actions have been taken to better respond to changing customer needs and the overall market condition. For instance more retailers now offer entertainment activities such as games, attractions, and cooking demonstrations. Or, in order to boost consumer confidence in scanner checkouts, a few retailers promise to give free merchandise if the price was not correct. These market-oriented efforts should lead to significantly more positive image and that, in turn, should produce a positive financial impact.

The results of this study should be interpreted cautiously. In the interests of obtaining a higher response rate and remaining within budgetary constraints, the use of single informant was necessary in this study. The use of information from only a single source to generalise about an organisation's condition may be misleading. Such information is selective, if not biased, owing to the informant's position or other characteristics or his/her way of using and weighting the information when making judgements (Philips 1981). Achrol 
(1991) suggests the use of multiple informants because multiple informants eliminate errors resulting from the one informant's selective perception, thus increasing reliability. However, multirespondent studies are relatively few in number, due to the cooperation required and coordination within subject firms and consequently are much more difficult to execute (Slater 1995).

This study employs manager's reports for assessing firm performances. Recently, several retail authors have sug- gested using customer perception or behaviour as a basis for measuring performance output of the retailing, which are perceived service quality, customer satisfaction and customer loyalty (Spreng and Mackoy 1996; Magi and Julander 1996). These outcomes can be thought of as the marketing assets that are leveraged to produce superior financial performances. Therefore, it is very useful to measure customer perceptions for measuring firm performances.

\section{References}

Abramson, N. R., and J. X. Ai. 1998. Practicing relationship marketing in Southeast Asia: Reducing uncertainty and improving performance. Management International Review 38: 113-44.

Achrol, R. S. 1991. Evolution of the marketing organization: New forms of turbulent environments. Journal of Marketing 55 (Oct): 77-93.

Ailawadi, K. L., N. Borin, and P. W. Farris. 1995. Market power and performance: A cross-industry analysis of manufacturers and retailers. Journal of Retailing 71 (3): 211-249.

Avlonitis, G. J., and S. P. Gounaris. 1997. Marketing orientation and company performance: A comparative study of industrial vs. consumer goods companies. Industrial Marketing Management 26 (5).

Bagozzi, R.P., and Y. Yi,L. W.Phillips. 1991. Assessing construct validity in organisational research. Administrative Science Quarterly 36 (3): 421-38.

Baker, W. E., and J. M. Sinkula . 1999. The synergistic effect of market orientation and learning organisation on organisational performance. Academy of Marketing Science 27 (4): 411-27.

Bartz, C. K., and M. C. Baetz. 1998. The relationship between mission statements and firm performance: An exploratory study. Journal of Management Studies 35 (6).

Brady, M. K., and J. J. Cronin Jr. 2001. Customer orientation: Effects on customer service perceptions and outcome behaviours. Journal of Service Research 3 (3): 241-251.

Brignall, T. J., L. Fitzgerald, R. Johnston, and R. Silvestro. 1991. Performance measurement in service businesses. Management Accounting (November): 34-36.

Brignall, T. J., and J. Ballantine. 1996. Performance measurement in service businesses revisited. International Journal of Service Industry Management 7 (1): 6-31. 
Soehadi-The Relationships among Different Performance Measures in Indonesian Retail Context

Bhuian, S. N. 1997. Exploring market orientation in banks: An empirical examination in Saudi Arabia. The Journal of Services Marketing 11 (5): 317-38.

Bourgeois III, L. J. 1980. Performance and consensus. Strategic Management Journal 1: $227-48$.

Bradley, K., and S. Taylor. 1992. Business Performance in the Retail Sector: The Experience of the John Lewis Partnership. Oxford: Clarendom Press.

Broeren, M. A. 1981. Perspective on profit. Retail Control 50 (September): 39-46.

Burt, S. and L. Sparks. 1997. Structural change in grocery retailing in great Britain: A discount reorientation? International Review of Retail and Distribution: 195-217.

Buzzell, R. D., and F. D. Wiersema. 1981. Modelling changes in market share: A crosssectional analysis. Strategic Management Journal (January-February): 27-42.

Byrne, B. M. 1989. A Primer of LISREL: Basic Applications and Programming for Confirmatory Factor Analytic Models. Springer-Verlag.

Capon, N., J. U. Farley, and S. Hoenig. 1990. Determinants of financial performance: A meta analysis. Management Science 36 (October): 1143-1160.

Chakravarthy, B. J. 1986. Measuring strategic performance. Strategic Management Journal 7: 437-58.

Chang, T. Z., R. Mehta, S. J. Chen, P. Polsa, and J. Mazur. 1999. The effect of market orientation on effectiveness and efficiency: The case of automotive distribution channels in Finland and Poland. Journal of Services Marketing 13 (4/5): 407-18.

Churchill, G. A., Jr. 1979. A Paradigm for developing better measures of marketing constructs. Journal of Marketing 26 (February): 64-73.

Clark, B. H. 1999. Marketing performance measures: History and interrelationships. Research Seminar: Assessing Marketing Performance. Berkshire: The Chartered Institute of Marketing.

Conant, J. S., D. T. Smart, and R. Solano-Mendez. 1993. Generic retailing types, distinctive marketing competencies, and competitive advantage. Journal of Retailing 69 (Fall).

Covin, J. G., and D. R. Slevin 1989. Strategic management of small firms in hostile and benign environments. Strategic Management Journal 10: 75-87.

Covin, J. G. 1991. Entrepreneurial versus conservative firms: A comparison of strategies and performance. Journal of Management Studies 28: 439-462.

Cronin, J. J., and S. J. Skinner. 1984. Marketing outcomes, financial conditions, and retail profit performance. Journal of Retailing 60 (4): 9-22.

Day, G. S. 1994. Continuous learning about markets. California Management Review 36 (4): 9-24.

Davies, E., and J. Kay. 1990. Assessing corporate performance. Business Strategy Review 1 (2): 1-16. 
Dawes, J. 2000. Market orientation and company profitability: Further evidence incorporating longitudinal data. Australian Journal of Management 25 (2): 173-91.

Deshpande, R. 1983. Paradigms lost: On theory and method in research marketing. 47 (Fall): 101-10.

Dess, G. G., and R. B. Robinson, Jr. 1984. Measuring organisational performance in the absence of objective measures: The case of the privately-held firms and conglomerate business unit. Strategic Management Journal 5 (July-September): 265-73.

Diamantopoulos, A., and S. Hart. 1993. Linking market orientation and company performance: Preliminary evidence on Kohli and Jaworki's Framework. Journal of Strategic Marketing 1(2): 93-122.

Doyle, P., and G. J. Hooley. 1992. Strategic orientation and corporate performance. International Journal of Research in Marketing 9: 59-73.

Droge, C., and R. Germain. 2000. The relationship of electronic data interchange with inventory and financial performance. Journal of Business Logistics 21 (2): 209-230.

Duncan, D. J., S. C. Hollander, and R. Savitt. 1983. Modern Retailing Management. New York: Wiley.

Edgett, S., and K. Snow. 1996. Benchmarking measures of customer satisfaction, quality and performance for new financial service products. The Journal of Service Marketing 10 (6): 6-17.

Fitzgerald, L., R. Johnston, T. J. Brignall, R. Silvestro, and V. Voss. 1991. Performance Measurement in Service Business. London: CIMA.

Greenley, G. E. 1995a. Market orientation and company performance: Empirical evidence from UK companies. British Journal of Management 6 (Mar): 1-13.

1995b. Forms of market orientation in UK companies. Journal of Management Studies 32 (January): 47-65.

Greenley, G. E., and G. R. Foxall. 1998. External moderation of associations among stakeholder orientations and company performance. International Journal of Research in Marketing 15: 51-69.

Han, J. K., N. Kim, and R. K. Srivastava. 1998. Market orientation and organisational firm: Is innovation a missing link. Journal of Marketing 62 (October): 30-45.

Hart, S., and N. Tzokas. 1999. The impact of marketing research activity on SME performance: Evidence from the UK. Journal of Small Business Management 37 (2): 63-75.

Hooley, G. J., J. E. Lynch, and J. Shepherd. 1990. The marketing concept: Putting theory into practice. European Journal of Marketing 24 (9): 7-22.

Hopkins, W. E., and S. A. Hopkins. 1997. Strategic planning -financial performance relationships in banks: A causal examination. Strategic Management Journal 18 (8): 635-652. 
Soehadi-The Relationships among Different Performance Measures in Indonesian Retail Context

Hurley, R. F., G. Thomas, and M. Hult. 1998. Innovation, market orientation, and organisational learning: An integration and empirical examination. Journal of Marketing 62 (July): 42-55.

Ingene, C. A. 1982. Productivity in retailing. Journal of marketing 46 (Fall): 75-90.

Ingene, C. A. 1984. Productivity and functional shifting in spatial retailing: Private and social perspectives. Journal of Retailing 60 (3).

Jaworski, B. J., and A. K. Kohli. 1993. Market orientation: Antecedents and consequences. Journal of Marketing 57 (July).

Judd, L. L., and B. C. Vaught. 1988. Three differential variables and their relation to retail strategy and profitability. Academy of Marketing Science 16 (Fall) (3and4): 30-37.

Kaplan, R. S., and D. P. Norton. 1992. The balanced scorecard - measures that drive performance. Harvard Business Review (January-February): 71-79.

Kohli A. K., B. J. Jaworski, and A. Kumar. 1993. MARKOR: A measure of market orientation. Journal of Marketing 30 (November).

Langerak, F., J. M. Ten Napel, R. Frambach, and H. R. Commandeur. 1997. Exploratory results on the moderating influence of strategy on the market orientation performance relationship. In Marketing: Progress Prospects Perspectives 2: 704-717. D. Arnott et al. (eds.). 26 $6^{\text {th }}$ EMAC Conference 20-23 May 1997 in Warwick Business School, Proceedings.

Lewis, P., and H. Thomas. 1990. The linkage between strategy, strategic groups, and performance in the UK retail grocery industry. Strategic Management Journal 11: 385-397.

Li, M., and R. L. Simerly. 1998. The moderating effect of environmental dynamism on the ownership and performance relationship. Strategic Management Journal 19: 16979.

Liu, H., and G. Davies. 1997. Market orientation in UK multiple retail companies: Nature and pattern. International Journal of Service Industry Management 8 (2): 170-187.

Lukas, B. A., and O. C. Ferrel. 2000. The effect of market orientation on product innovation. Academy of Marketing Science 28 (2): 239-47.

Luo, Y., and M. W. Peng. 1999. Learning to compete in a transition economy: Experience, environment, and performance. Journal of International Business 30 (2): 269-296.

Magi, A., and C. R. Julander. 1996. Perceived service quality and customer satisfaction in a store performance framework: An empirical study of Swedish grocery retailers. Journal of Retailing and Consumer Services 3 (1): 33-41.

Martin,Jr., C. R. 1996. Retail service innovations: Inputs for success. Journal of Retailing and Consumer Services 3 (2): 63-71. 
Matheson, P. K., B. J. Gray, and S. M. Matear. 1999. A multi-dimensional measure of relative business performance. In Research Seminar: Assessing Marketing Performance. T. Ambler (ed.). Berkshire: The Chartered Institute of Marketing.

Matsuno, K., and J. T. Mentzer. 2000. The effects of strategy type on the market orientation-performance relationship. Journal of Marketing 64 (4): 1-18.

Mc.Gee, J. E., and M. Peterson. 2000. Toward the development of measures of distinctive competencies among small independent retailers. Journal of Small Business Management 38 (2): 19-33.

McGurr, P. T., and S. A. DeVaney. 1998. A retail failure prediction model. The International Review of Retail, Distribution and Consumer Research 8 (3): 259-276.

Narver, J. C., and S. F. Slater. 1990. The effect of a market orientation on business profitability. Journal of Marketing 54 (October).

O'Riordan, D. 1993. Retail gross margins: Some international comparisons. International Journal of Retail and Distribution Management 21 (4): 33-40.

Orvis, B. T. 1996. Market orientation and organizational performance: A multi-level analysis in a retail setting. Unpublished Dissertation. University of Oklahoma.

Pearce, M. 1998. The retail performance dynamic. Ivey Business Quaterly 62 (4): 62-62.

Pelham, A. M. 1997. Market orientation and performance: The moderating effects of product and customer differentiation. Journal of Business and Industrial Marketing 12 (5): 276-296.

Pelham, A. M. 2000. Market orientation and other potential influences on performance in small medium-sized manufacturing firms. Journal of Small Business Management 38 (1): 48-67.

Phillips, L. W. 1981. Assessing measurement error in key informant reports: A methodological note an organisational analysis in marketing. Journal of Marketing Research 17 (November): 395-415.

Ruekert, R. W. 1992. Developing a market orientation: An organizational strategy perspective. International Journal of Research In Marketing 9: 225-45.

Sargeant, A., and M. Mohamad. 1999. Business performance in the UK hotel sector Does it pay to be market oriented? The Service Industries Journal 19 (3): 42-59.

Slater, S. F., and J. C. Narver. 1994. Does competitive environment moderate the market orientation performance relationship? Journal of marketing 58 (January): 46-55.

Slater, S. F. 1995. Issues in conducting marketing strategy. Journal of Strategic Marketing 3: $257-270$.

Soehadi, A. W., S. Hart, S. Tagg. 2001. Measuring market orientation in Indonesian retail context. Journal of Strategic Marketing.

Spreng, R. A., and R. D. Mackoy. 1996. An empirical examination of a model service quality and satisfaction. Journal of Retailing 72 (2): 201-14. 
Soehadi-The Relationships among Different Performance Measures in Indonesian Retail Context

Siguaw, J. A., P. M. Simpson, and T. L. Baker. 1998. Effects of supplier market orientation on distributor market orientation and the channel relationship: The distributor perspective. Journal of Marketing 62 (July): 99-111.

Srivastava, R. K., T. A. Shervani, and L. Fahey. 1998. Market-based assets and shareholder value: A framework for analysis. Journal of Marketing 62 (1): 2-18.

Tan, K. C., V. R. Kannan, and R. B. Hanfield. 1998. Supply chain management: Supplier performance and firm performance. Journal of Supply Chain Management 34 (3): 29.

Varadarajan, P. R., and V. Ramanujam. 1990. The corporate performance conundrum: A synthesis of contemporary views and an extension. Journal of Management Studies 27 (5): 463-83.

Venkatraman, N., and V. Ramanujam. 1986. Measurement of business performance in strategy research: A comparison approach. Academy of Management Review 11 (October): 801-814.

Verhees, F. 1998. Market orientation, product innovation and company performance. In Marketing Research and Practice. P. Anderson, (ed.), 27 ${ }^{\text {th }}$ EMAC Conference, Stockholm $20^{\text {th }}-, 23^{\text {rd }}$.

Vorhies, D. W., M. Harker, and C. P. Rao. 1999. The capabilities and performance advantages of market-driven firms. European Journal of Marketing 33 (11/12): 1171-202.

Weitzel, W., A. B. Schwartzkopf, and E. B. Peach. 1989. The influence of employee perceptions of customer service on retail store sales. Journal of Retailing 65 (1): 27 40 . 
GadjahMadaInternationalJournal ofBusiness, May2002, Vol.4,No. 2

\section{APPENDIX 1. Market Orientation Construct (Four Correlated Factors)}

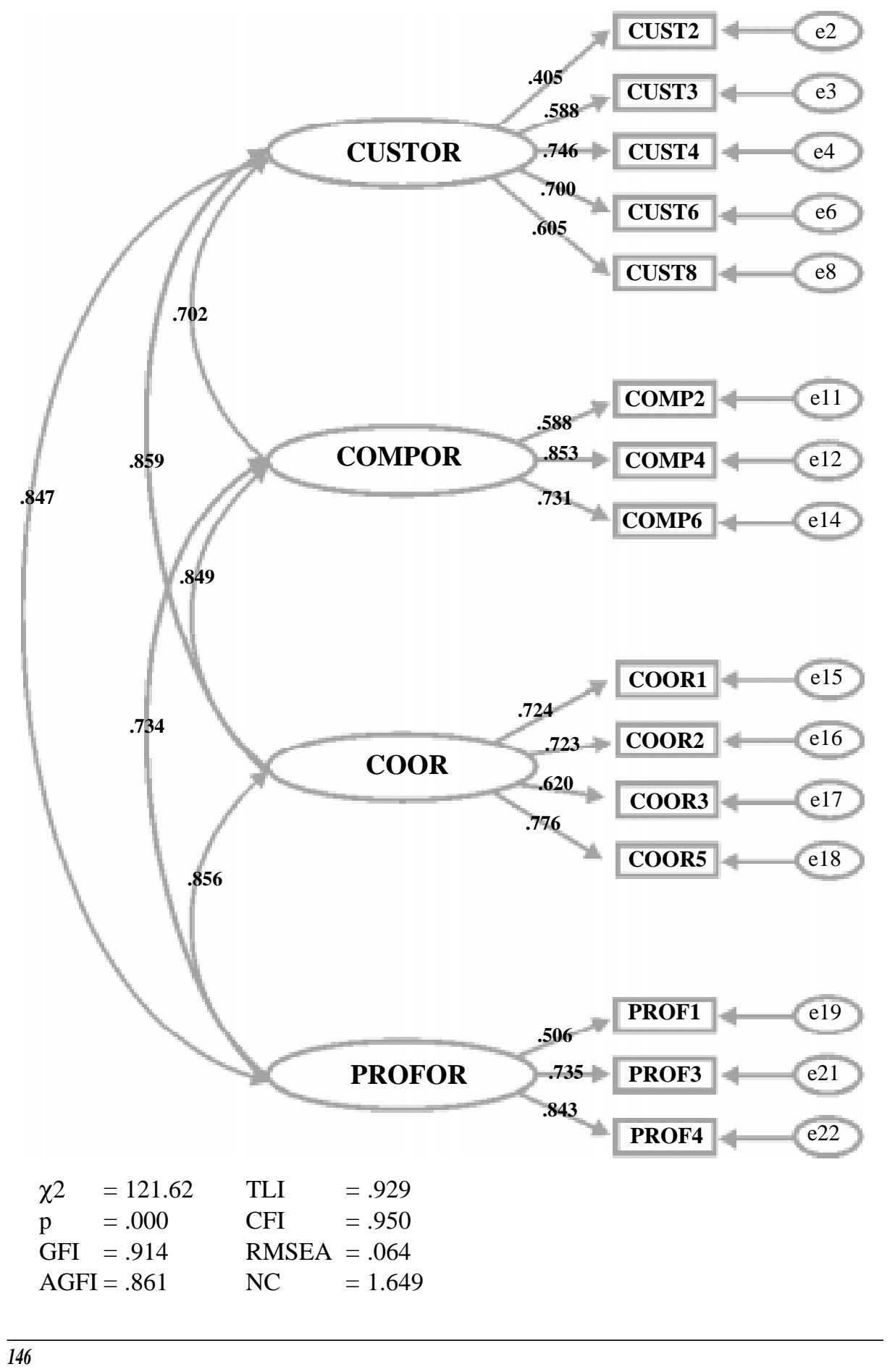


Soehadi-The Relationships among Different Performance Measures in Indonesian Retail Context

\section{APPENDIX 1. Indirect and Direct Measures}

Nonfinancial Indicators

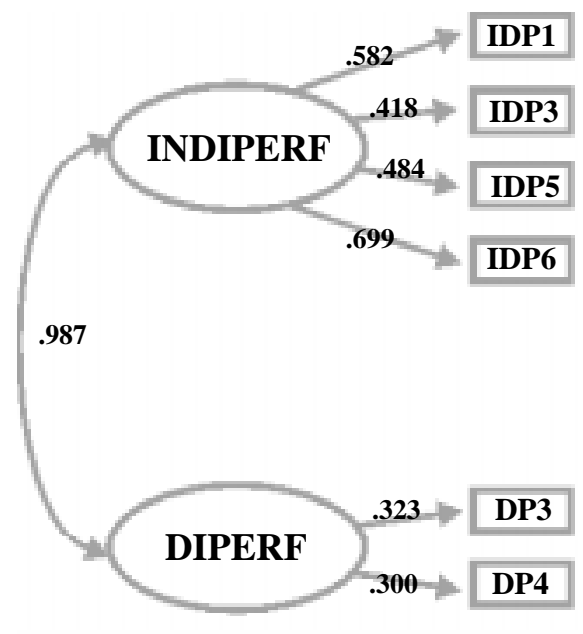

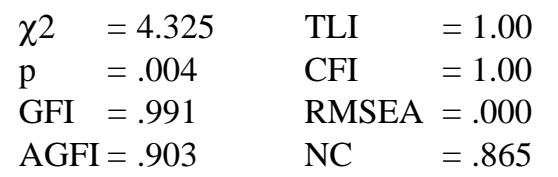

Financial Indicators

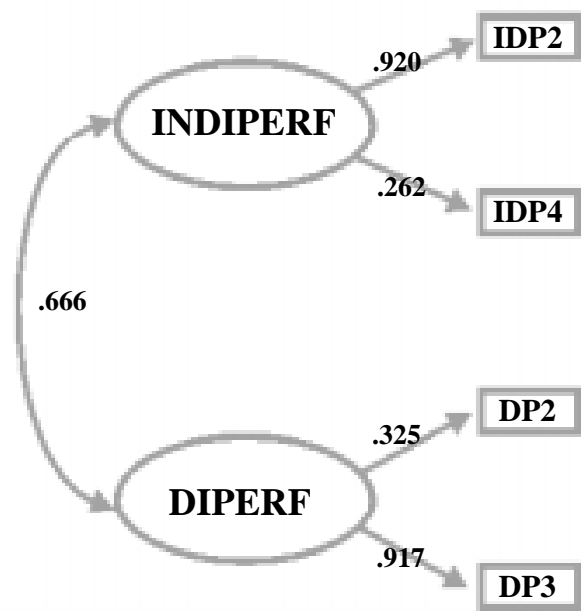

\begin{tabular}{|c|c|c|c|}
\hline$x^{2}$ & $=2.089$ & TLI & \\
\hline $\mathrm{p}$ & $=.148$ & CFI & \\
\hline GFI & $=.993$ & RMSEA & \\
\hline $\mathrm{AGFl}$ & $=.935$ & $\mathrm{NC}$ & \\
\hline
\end{tabular}

